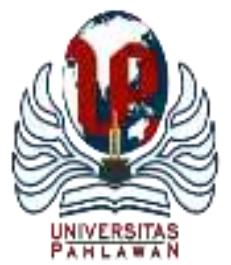

Edukatif : Jurnal Ilmu Pendidikan Volume 4 Nomor 1 Tahun 2022 Halm 732 - 746 EDUKATIF: JURNAL ILMU PENDIDIKAN

Research \& Learning in Education

https://edukatif.org/index.php/edukatif/index

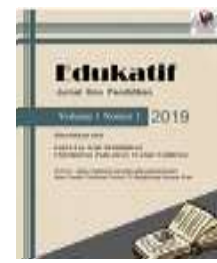

\title{
Analisis Hasil Survei SPADA Dikti 2021 dan Dampaknya Terhadap Rekomendasi Kebijakan Implementasi Kampus Merdeka
}

\author{
Sri Supatmi ${ }^{1 凶}$, Budi Herdiana ${ }^{2}$, Jana Utama ${ }^{3}$, Muhammad Aria Rajasa Pohan ${ }^{4}$, \\ Tri Rahajoeningroem ${ }^{5}$ \\ Universitas Komputer Indonesia, Indonesia ${ }^{1,2,3,4,5}$ \\ E-mail : sri.supatmi@email.unikom.ac.id ${ }^{1}$, budi.herdiana@email.unikom.ac.id ${ }^{2}$, \\ jana.utama@email.unikom.ac.id ${ }^{3}$, muhammad.aria@email.unikom.ac.id ${ }^{4}$, \\ tri.rahajoeningroem@email.unikom.ac.id
}

\begin{abstract}
Abstrak
Program implementasi kebijakan Merdeka Belajar Kampus Merdeka (MBKM) dalam pelaksanaannya dimungkinkan akan selalu muncul permasalahan terhadap kebijakan pelaksanaannya. Dari semua kemungkinan permasalahan ini, maka tujuan yang diharapkan adalah ingin mengetahui dampak nyata implementasi kebijakan program MBKM terhadap proses belajar mengajar apabila terapkan dalam lingkungan Program Studi Teknik Elektro Universitas Komputer Indonesia. Hasil analisis dari dampak implementasi ini akan dijadikan rekomendasi penerapan model pembelajaran MBKM sesuai kebutuhan dan kemampuan program studi. Untuk memperoleh ketercapaian hasilnya, maka metode yang digunakan melalui pendekatan metode survei terhadap pelaku dan pengguna kebijakan yaitu mahasiswa, dosen, dan tenaga pendidikan di dalam lingkungan program studi. Hasil penelitian menunjukkan bahwa tingkat pemahaman responden mahasiswa terhadap program MBKM, sebagian besar responden mahasiswa berpendapat pada rentang nilai "Berdampak", yaitu sebanyak 56\% responden. Kesiapan mahasiswa mengikuti program MBKM, sebagian besar responden mahasiswa berada pada rentang skor "Cukup Siap" yaitu sebanyak $45 \%$ responden. Responden mahasiswa yang menyatakan kegiatan MBKM berimplikasi pada lama masa studi, didapati $52 \%$ responden berpendapat masih dapat lulus tepat waktu. Hanya sebagian kecil responden, yaitu sebanyak 17\% responden yang khawatir dapat memperlama masa studi.
\end{abstract}

Kata Kunci: Merdeka Belajar Kampus Merdeka (MBKM), responden, kebijakan prodi Teknik Elektro.

\begin{abstract}
The program for implementing the Independent Learning Campus (MBKM) policy in its implementation is possible there will always be problems with its implementation policy. From all these possible problems, the expected goal is to find out the real impact of the implementation of the MBKM program policy on the teaching and learning process when applied in Electrical Engineering UNIKOM. The results of the analysis of the impact of this implementation are used as recommendations for implementing the MBKM learning model according to the needs and abilities of the study program. To achieve this, the method used is through a survey method approach to policy actors and users, namely students, lecturers, and education staff in the Electrical Engineering, UNIKOM. The results showed that $56 \%$ of respondents understood the MBKM program. The level of readiness of students to take part in the MBKM program, as many as $45 \%$ of respondents stated "Quite Ready". Student respondents who stated that MBKM activities had implications for the length of the study period, it was found that $52 \%$ of respondents thought they could still graduate on time and as many as $17 \%$ of respondents were worried that they could prolong the study period.
\end{abstract}

Keywords: Merdeka Belajar Kampus Merdeka (MBKM), respondents, policy of Electrical Engineering major.

Copyright (c) 2022

Sri Supatmi, Budi Herdiana, Jana Utama, Muhammad Aria Rajasa Pohan, Tri Rahajoeningroem

$\triangle$ Corresponding author:

Email : sri.supatmi@email.unikom.ac.id

DOI : https://doi.org/10.31004/edukatif.v4i1.1894 
733 Analisis Hasil Survei SPADA Dikti 2021 dan Dampaknya Terhadap Rekomendasi Kebijakan Implementasi Kampus Merdeka - Sri Supatmi, Budi Herdiana, Jana Utama, Muhammad Aria Rajasa Pohan, Tri Rahajoeningroem

DOI: https://doi.org/10.31004/edukatif.v4i1.1894

\section{PENDAHULUAN}

Dalam menghadapi perubahan sosial, budaya, dunia kerja dan kemajuan teknologi yang pesat saperti saat ini, setiap perguruan tinggi dituntut harus dapat menyiapkan para lulusan yang memiliki kompetensi dengan kebutuhan zaman (Rosmiati.; Putra, 2021; Yuni et al., 2016). Dimana saat ini terdapat mahasiswa di Program Studi (Prodi) Teknik Elektro yang mengikuti kegiatan MBKM yaitu Program Mahasiswa Merdeka dan Program Intership Pejuang Muda. Oleh karena itu, Prodi Teknik Elektro UNIKOM harus dapat merancang dan melaksanakan proses pembelajaran yang kreatif dan inovatif. Hal ini perlu dilakukan agar mahasiswa dapat mencapai pembelajaran yang meliputi aspek sikap, pengetahuan, dan keterampilan secara optimal dan selalu relevan dengan kebutuhan zaman. Agar dapat mencapai hal tersebut tentunya Prodi Teknik Elektro harus menyusun kebijakan dengan tepat sehingga nantinya kebijakan tersebut dapat dirasakan manfaatnya oleh mahasiswa melalui program MBKM tersebut. Agar tercipta kultur belajar yang inovatif, tidak mengekang, dan sesuai dengan kebutuhan mahasiswa, maka perguruan tinggi peluru melaksanakan pembelajaran yang otonom dan inovatif (Azizah et al., 2021). Perguruan tinggi dituntut untuk dapat merancang dan melaksanakan proses pembelajaran yang inovatif agar mahasiswa dapat meraih capaian pembelajaran mencakup aspek sikap, pengetahuan, dan keterampilan secara optimal dan selalu relevan (Sudaryanto.; Widayati, 2020). Dalam rangka menyiapkan mahasiswa menghadapi perubahan sosial, budaya, dunia kerja dan kemajuan teknologi yang pesat, kompetensi mahasiswa harus disiapkan untuk lebih relevan dengan kebutuhan zaman (Prahani et al., 2020).

Adapun penelitian-penelitian yang terkait yang telah dilakukan oleh, (Nanggala, 2020) menganalisis konsep kampus merdeka dalam perspektif Pendidikan Kewarganegaraan.dengan orientasi agar kebijakan kampus merdeka dalam tataran praksisnya tidak bersifat prosedural serta pragmatis. (Lestiyani, 2020) menganalisis persepsi dari para pelaku pendidikan (civitas akademika) terhadap kebijakan Merdeka Belajar di SMA Negeri 1 Sidareja Kabupaten Cilacap Provinsi Jawa Tengah. (Yuliana, 2020) melakukan analisis Proses Pembelajaran Norma dan Keadilan Pada PPKN dalam kebijakan Merdeka Belajar Bagi Siswa Kelas VII SMP Negeri 23 Surakarta. Dari penelitian-penelitian yang ada, belum ada yang mengangkat penelitian yang terkait dengan kebijakan Prodi Teknik Elektro terkait dengan program MBKM ini. Maka dari itu, pembaruan yang dilakukan pada penelitian ini untuk mengetahui dampak implementasi program Kampus Merdeka-Merdeka Belajar terhadap proses belajar mengajar di lingkungan Prodi Teknik Elektro UNIKOM. Hal ini sangat penting untuk dapat memperbaiki dan menyesuaikan kebijakan belajar yang fleksibel sesuai dengan kebutuhan mahasiswa agar menjadi lebih baik.

\section{METODOLOGI PENELITIAN}

Metode pelaksanaan pada penelitian ini adalah survei melalui kuesioner menggunakan bantuan platform Googleform terhadap pelaku dan pengguna program kebijakan MBKM. Dengan melalui pengisian survei yang memfokuskan pada indikator-indikator yang berhubungan dengan dampak kebijakan terhadap mahasiswa, dosen dan tenaga pendidik di lingkukan program studi Teknik Elektro Universitas Komputer Indonesia. Adapun penelitian ini memiliki 3 indikator kinerja penelitian yaitu: Indikator pertama, untuk menghasilkan analisis mengenai keterkaitan antara pemahaman responden mengenai MBKM terhadap media informasi yang digunakan oleh responden untuk mendapatkan informasi mengenai kebijakan MBKM. Indikator kedua, untuk menghasilkan analisis mengenai keterkaitan antara opini responden mengenai dampak MBKM terhadap bentuk kegiatan MBKM yang diminati oleh mahasiswa. Dan yang ketiga, untuk menghasilkan analisis mengenai keterkaitan antara kesiapan mahasiswa untuk mengikuti program MBKM dengan kendala yang dihadapi. Adapun alur penelitian yang dilakukan, seperti yang ditunjukan pada Gambar 1. 
734 Analisis Hasil Survei SPADA Dikti 2021 dan Dampaknya Terhadap Rekomendasi Kebijakan Implementasi Kampus Merdeka - Sri Supatmi, Budi Herdiana, Jana Utama, Muhammad Aria Rajasa Pohan, Tri Rahajoeningroem

DOI: https://doi.org/10.31004/edukatif.v4i1.1894

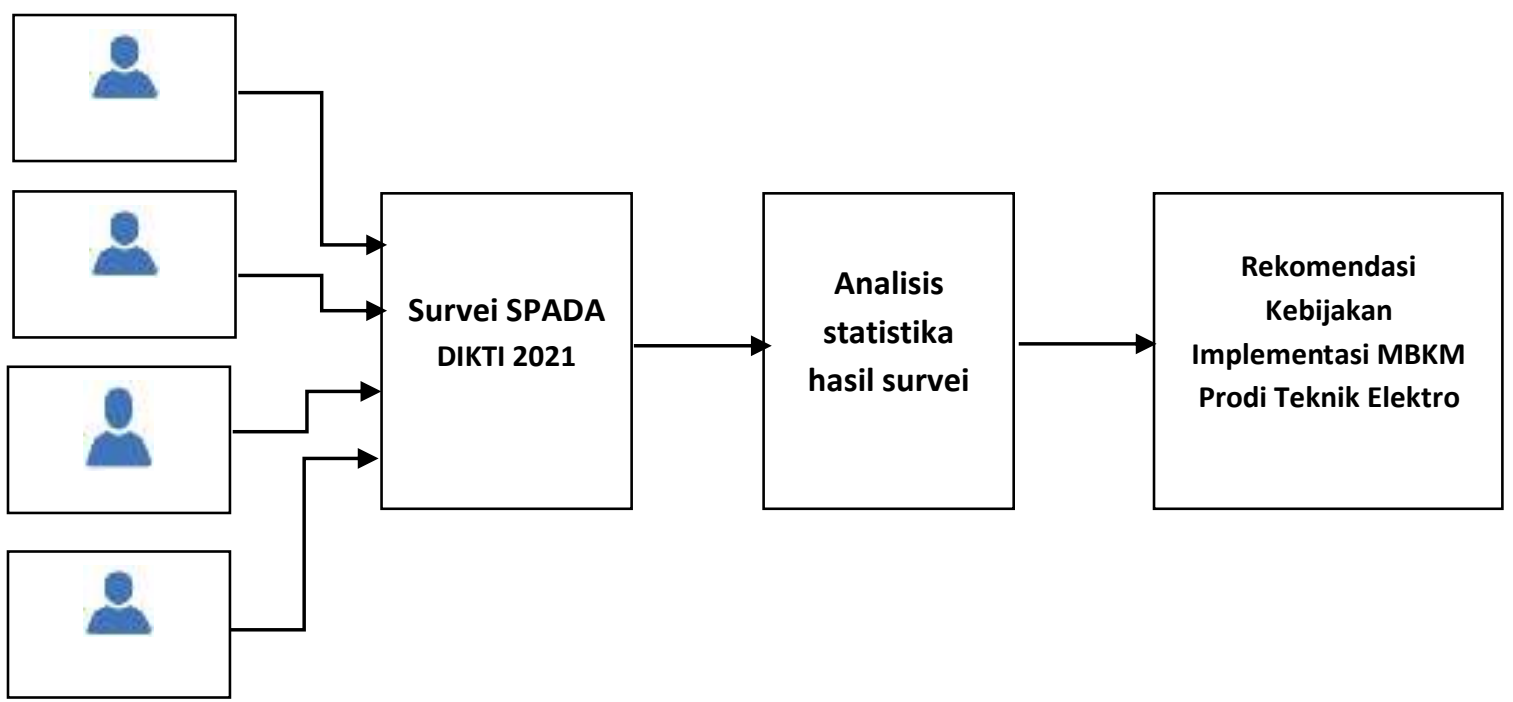

Gambar 1. Pelaksanaan penelitian MBKM berdasarkan survei spada dikti 2021

\section{HASIL DAN PEMBAHASAN PENELITIAN}

Pada dasarnya kebijakan program Merdeka Belajar Kampus Merdeka (MBKM) merupakan konsep merdeka belajar yang merujuk pada kebebasan mutlak bagi masyarakat untuk belajar secara adaptif. Kebijakan ini memberikan peluang lahirnya model pembelajaran inventif mandiri disesuaikan kemampuan peserta didik dengan mengedepankan pembelajaran melalui model terjun langsung dalam kehidupan nyata. Disisi lain, dosen diharuskan menyusun, melaksanakan, dan menilai proses pembelajarannya yang dituntut untuk dapat menyesuaikan diri dengan teknologi sebagai media perantara belajar. Perwujudan Kampus Merdeka menjadikan perguruan tinggi menjadi lebih otonom dan mempu menyesuaikan dirinya dengan kondisi lingkungan dinamis sehingga tercipta kultur belajar yang lebih inovatif, produktif, tidak kaku dan sesuai dengan kemampuan peserta didik. Karena itu, pada penelitian ini semua informasi data dan jumlah responden yang menjadi sumber data diambil dari hasil pandangan mahasiswa, dosen dan tenaga pendidikan sebagai komponen-komponen utama untuk melihat dampak atau implikasi nyata diberlakukan kebijakan Merdeka Belajar Kampus Merdeka dalam seluruh aktivitas pembelajaran pada Program Studi Teknik Elektro Universitas Komputer Indonesia.

Sesuai dengan tujuan penelitian ini yaitu untuk mengukur analisis dampak hasil survei yang akan menentukan kelayakan dan rekomendasi program kebjakan MBKM di program studi Teknik elektro universitas Komputer Indonesia yang indikator keputusannya didasari oleh 3 parameter yaitu tingkat pemahaman dan pengetahuan responden, tingkat kesiapan responden dan kendala yang mungkin muncul. Data hasil survei dikumpulkan menggunakan Google form guna efesiensi waktu pengumpulan data.

\section{Analisis 1: Metode dan Hasil Pengukuran Pemahaman Responden terhadap Program MBKM}

Pertama-tama akan dilakukan analisis mengenai pemahaman responden mahasiswa terhadap program MBKM ini. Pertanyaan-pertanyaan pada kuesioner dinilai dapat merepresentasikan pemahaman responden terhadap program MBKM ini ditunjukkan pada Tabel 1. Nilai numerik dari jawaban pertanyaan setiap mahasiswa untuk nomor 1, 2, 3, 6, dan 9 akan dijumlahkan lalu dirata-ratakan. Nilai rata-rata ini akan dijadikan sebagai nilai pemahaman responden mahasiswa terhadap program MBKM ini. Panduan konversi nilai rata-rata terhadap tingkat pemahaman responden mahasiswa ditunjukkan pada Tabel 2. Maka berdasarkan proses pengukuran yang telah dijelaskan pada Tabel 1 dan Tabel 2, dapat diperoleh tingkat pemahaman responden mahasiswa terhadap program MBKM ini seperti yang disajikan pada Gambar 2. Dapat 
735 Analisis Hasil Survei SPADA Dikti 2021 dan Dampaknya Terhadap Rekomendasi Kebijakan Implementasi Kampus Merdeka - Sri Supatmi, Budi Herdiana, Jana Utama, Muhammad Aria Rajasa Pohan, Tri Rahajoeningroem

DOI: https://doi.org/10.31004/edukatif.v4i1.1894

terlihat bahwa sebagian besar responden mahasiswa berada pada tingkat pemahaman "Cukup" (38\% responden).

\section{Tabel 1}

Pertanyaan-pertanyaan pada kuesioner mahasiswa yang digunakan untuk mengukur pemahaman responden mengenai program MBKM

\begin{tabular}{|c|c|c|c|}
\hline $\begin{array}{c}\text { Nomor } \\
\text { Pertanyaan }\end{array}$ & Isi Pertanyaan & Pilihan Jawaban & $\begin{array}{c}\text { Konversi } \\
\text { Jawaban pada } \\
\text { Nilai Numerik } \\
\end{array}$ \\
\hline \multirow{4}{*}{1} & \multirow{4}{*}{$\begin{array}{l}\text { Seberapa jauh Saudara mengetahui tentang } \\
\text { kebijakan Merdeka Belajar-Kampus Merdeka } \\
(\text { MBKM)? }\end{array}$} & $\begin{array}{l}\text { Mengetahui kebijakan secara } \\
\text { keseluruhan. }\end{array}$ & 5 \\
\hline & & $\begin{array}{l}\text { Mengetahui sebagian besar isi } \\
\text { kebijakannya. }\end{array}$ & 3,33 \\
\hline & & Mengetahui sedikit. & 1,67 \\
\hline & & $\begin{array}{l}\text { Belum mengetahui sama } \\
\text { sekali. }\end{array}$ & 0 \\
\hline \multirow{2}{*}{2} & \multirow{2}{*}{$\begin{array}{l}\text { Menurut saudara, hingga berapa semester } \\
\text { yang bisa disetarakan dengan bentuk kegiatan } \\
\text { MBKM di luar Perguruan Tingginya? }\end{array}$} & 2 & 5 \\
\hline & & Selain 2 semester & 0 \\
\hline \multirow[b]{2}{*}{3} & \multirow{2}{*}{$\begin{array}{l}\text { Menurut saudara, hingga berapa sks yang bisa } \\
\text { disetarakan dengan bentuk kegiatan MBKM } \\
\text { di luar Perguruan Tingginya? }\end{array}$} & 40 & 5 \\
\hline & & Selain 40 sks & 0 \\
\hline \multirow[b]{2}{*}{6} & \multirow{2}{*}{$\begin{array}{l}\text { Apakah Program Studi Saudara mempunyai } \\
\text { program terdahulu yang sesuai dengan bentuk } \\
\text { kegiatan Merdeka Belajar-Kampus Merdeka } \\
(\text { MBKM)? }\end{array}$} & Ya & 5 \\
\hline & & Tidak & 0 \\
\hline \multirow{3}{*}{9} & \multirow{3}{*}{$\begin{array}{l}\text { Apakah dokumen kurikulum, panduan dan } \\
\text { prosedur operasional untuk mengikuti } \\
\text { kegiatan MBKM sudah ada pada program } \\
\text { studi saudara? }\end{array}$} & Sudah & 5 \\
\hline & & Belum & 5 \\
\hline & & Tidak Tahu & 0 \\
\hline
\end{tabular}

Tabel 2

Panduan skala pengukuran tingkat pemahaman responden terhadap program MBKM Nilai rata-rata pertanyaan $1,2,3,6$, dan 9 Skala pemahaman dari responden

\begin{tabular}{cc}
\hline $4-5$ & Sangat Paham (SP) \\
\hline $3-4$ & Paham (P) \\
\hline $2-3$ & Cukup Paham (CP) \\
\hline $1-2$ & Kurang Paham (KP) \\
\hline $0-1$ & Tidak Paham (TP)
\end{tabular}


736 Analisis Hasil Survei SPADA Dikti 2021 dan Dampaknya Terhadap Rekomendasi Kebijakan Implementasi Kampus Merdeka - Sri Supatmi, Budi Herdiana, Jana Utama, Muhammad Aria Rajasa Pohan, Tri Rahajoeningroem

DOI: https://doi.org/10.31004/edukatif.v4i1.1894

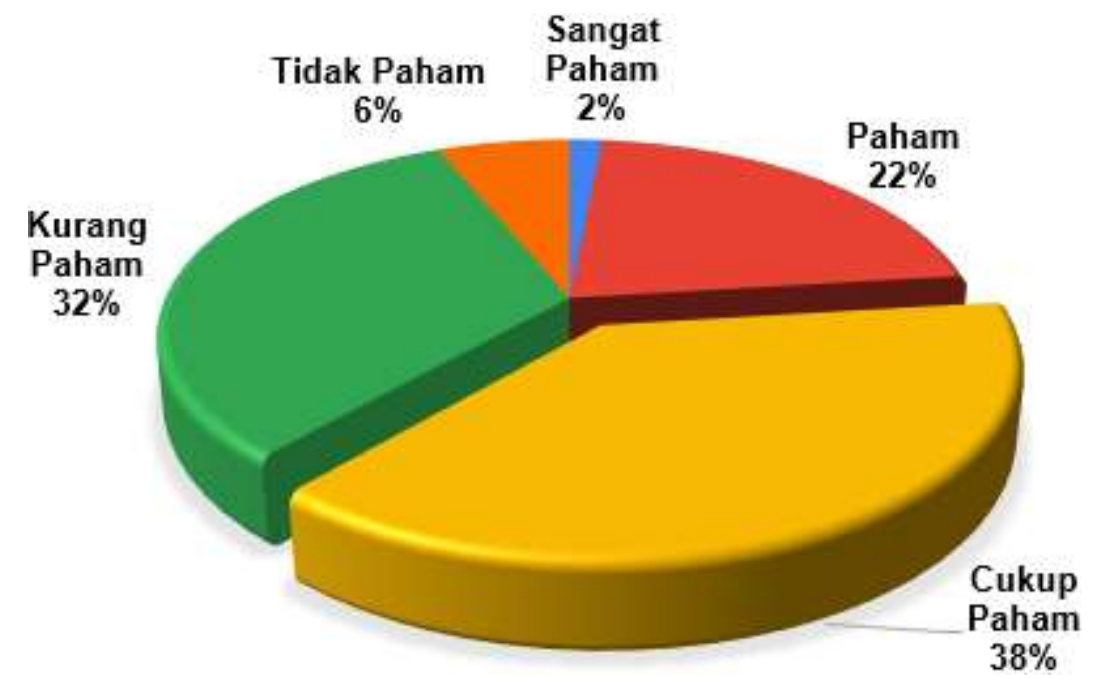

Gambar 2. Hasil analisis tingkat pemahaman responden mahasiswa terhadap program MBKM

Selanjutnya akan dilakukan analisis mengenai pemahaman responden dosen terhadap program MBKM ini. Pertanyaan-pertanyaan pada kuesioner dinilai dapat merepresentasikan pemahaman responden dosen terhadap program MBKM ini ditunjukkan pada Tabel 3. Nilai numerik dari jawaban pertanyaan setiap dosen untuk nomor 1, 2, 3, 6, 9, 13, dan 14 akan dijumlahkan lalu dirata-ratakan. Nilai rata-rata ini akan dijadikan sebagai nilai pemahaman responden dosen terhadap program MBKM ini. Panduan konversi nilai rata-rata terhadap tingkat pemahaman responden dosen sama dengan ditunjukkan pada Tabel 2. Maka dapat diperoleh tingkat pemahaman responden dosen terhadap program MBKM ini seperti yang disajikan pada Gambar 3. Dapat terlihat bahwa sebagian besar responden dosen berada pada tingkat pemahaman "Sangat Paham" (57\% responden).

Tabel 3

Pertanyaan-pertanyaan pada kuesioner mahasiswa yang digunakan untuk mengukur pemahaman responden mengenai program MBKM

\begin{tabular}{|c|c|c|c|}
\hline $\begin{array}{c}\text { Nomor } \\
\text { Pertanyaan }\end{array}$ & Isi Pertanyaan & Pilihan Jawaban & $\begin{array}{c}\text { Konversi } \\
\text { Jawaban pada } \\
\text { Nilai Numerik } \\
\end{array}$ \\
\hline \multirow{4}{*}{1} & \multirow{4}{*}{$\begin{array}{l}\text { Seberapa jauh Saudara mengetahui tentang } \\
\text { kebijakan Merdeka Belajar-Kampus Merdeka } \\
(\text { MBKM)? }\end{array}$} & $\begin{array}{l}\text { Mengetahui kebijakan secara } \\
\text { keseluruhan. }\end{array}$ & 5 \\
\hline & & $\begin{array}{l}\text { Mengetahui sebagian besar } \\
\text { isi kebijakannya. }\end{array}$ & 3,33 \\
\hline & & Mengetahui sedikit. & 1,67 \\
\hline & & $\begin{array}{l}\text { Belum mengetahui sama } \\
\text { sekali. }\end{array}$ & 0 \\
\hline \multirow[b]{2}{*}{2} & \multirow{2}{*}{$\begin{array}{l}\text { Pada SN-Dikti (Permendikbud No. } 3 \text { Tahun } \\
\text { 2020), hingga berapa semester yang dapat } \\
\text { digunakan untuk melakukan bentuk kegiatan } \\
\text { MBKM di luar Perguruan Tingginya? }\end{array}$} & 2 & 5 \\
\hline & & Selain 2 semester & 0 \\
\hline \multirow[b]{2}{*}{3} & \multirow{2}{*}{$\begin{array}{l}\text { Pada SN-Dikti (Permendikbud No. } 3 \text { Tahun } \\
\text { 2020), hingga berapa SKS yang dapat } \\
\text { digunakan untuk melakukan bentuk kegiatan } \\
\text { MBKM di luar Perguruan Tingginya? }\end{array}$} & 40 & 5 \\
\hline & & Selain 40 sks & 0 \\
\hline \multirow[b]{2}{*}{6} & \multirow{2}{*}{$\begin{array}{l}\text { Apakah Program Studi Saudara mempunyai } \\
\text { program terdahulu yang sesuai dengan } \\
\text { bentuk kegiatan Merdeka Belajar-Kampus } \\
\text { Merdeka (MBKM)? }\end{array}$} & $\mathrm{Ya}$ & 5 \\
\hline & & Tidak & 0 \\
\hline
\end{tabular}


737 Analisis Hasil Survei SPADA Dikti 2021 dan Dampaknya Terhadap Rekomendasi Kebijakan Implementasi Kampus Merdeka - Sri Supatmi, Budi Herdiana, Jana Utama, Muhammad Aria Rajasa Pohan, Tri Rahajoeningroem

DOI: https://doi.org/10.31004/edukatif.v4i1.1894

\begin{tabular}{|c|c|c|c|}
\hline \multirow[b]{4}{*}{9} & \multirow{4}{*}{$\begin{array}{l}\text { Apakah Perguruan Tinggi Saudara sudah } \\
\text { memiliki dokumen kebijakan terkait } \\
\text { kurikulum yang memfasilitasi Merdeka } \\
\text { Belajar-Kampus Merdeka? (dalam bentuk } \\
\text { peraturan rektor: panduan akademik atau } \\
\text { panduan implementasi MBKM, kurikulum } \\
\text { prodi untuk memfasilitasi MBKM) }\end{array}$} & Sudah ada dan sudah terbit. & 5 \\
\hline & & Baru berupa draft. & 5 \\
\hline & & Belum ada. & 5 \\
\hline & & Tidak Tahu. & 0 \\
\hline \multirow[b]{2}{*}{13} & \multirow{2}{*}{$\begin{array}{l}\text { Apakah Saudara sudah pernah mempelajari } \\
\text { buku panduan Merdeka Belajar-Kampus } \\
\text { Merdeka? }\end{array}$} & Sudah pernah & 5 \\
\hline & & Belum & 0 \\
\hline \multirow[b]{2}{*}{14} & \multirow{2}{*}{$\begin{array}{l}\text { Apakah Saudara sudah pernah mengikuti } \\
\text { sosialisasi dosen penggerak baik langsung } \\
\text { maupun mengikuti melalui youtube ditjen } \\
\text { dikti? }\end{array}$} & Sudah pernah & 5 \\
\hline & & Belum & 0 \\
\hline
\end{tabular}

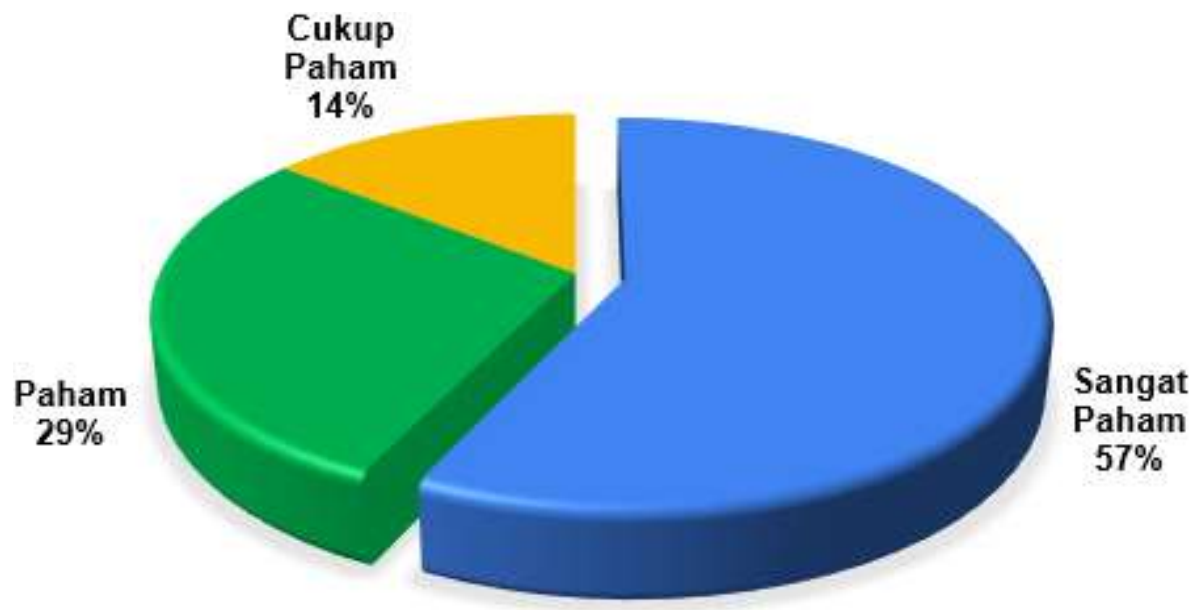

Gambar 3. Hasil analisis tingkat pemahaman responden dosen terhadap program MBKM

\section{Analisis 2: Keterkaitan antara Pemahaman Responden dengan Media Informasi yang Digunakan}

Berdasarkan hasil analisis $1 \mathrm{di}$ atas, selanjutnya akan dianalisis apakah ada keterkaitan antara pemahaman responden dengan media informasi yang digunakan. Berdasarkan pertanyaan nomor 4 dari kuesioner dengan responden mahasiswa, dapat diketahui media yang digunakan mahasiswa untuk mendapatkan informasi mengenai kebijakan MBKM. Tabel 4 menunjukkan pilihan-pilihan media yang digunakan mahasiswa untuk mendapatkan informasi MBKM tersebut. Tabulasi silang antara pemahaman responden mahasiswa dengan media informasi yang digunakan untuk mendapatkan informasi kebijakan MBKM dapat dilihat pada Tabel 5.

Berdasarkan hasil pada Tabel 5, dapat terlihat bahwa tiga media informasi yang paling berkaitan dengan pemahaman mahasiswa pada tingkat "Cukup Paham" hingga "Sangat Paham" adalah Media4, Media6 dan Media3. Jika dilihat pada Tabel 4, Ketiga media tersebut adalah "Kanal daring Perguruan Tinggi (laman/website, media sosial)", "Kanal daring Kemendikbud (laman/website, media sosial)", dan "Kegiatan sosialisasi luring/daring yang diselenggarakan oleh Perguruan Tinggi”. Pemanfaatan kanal daring (website) sebagai media informasi yang efektif juga dilaporkan oleh (Aunur Rahman et al., 2020; Fadillah, 2013; Nurina Aprilia \& Fefta Wijaya, 2014; Surentu, 2020). 
738 Analisis Hasil Survei SPADA Dikti 2021 dan Dampaknya Terhadap Rekomendasi Kebijakan Implementasi Kampus Merdeka - Sri Supatmi, Budi Herdiana, Jana Utama, Muhammad Aria Rajasa Pohan, Tri Rahajoeningroem

DOI: https://doi.org/10.31004/edukatif.v4i1.1894

Tabel 4

Daftar pilihan media informasi yang dapat digunakan mahasiswa untuk mendapatkan informasi mengenai kebijakan MBKM

\begin{tabular}{cc}
\hline Kode Media & Deskripsi \\
\hline Media6 & Kanal daring Kemendikbud (laman/website, media sosial). \\
\hline Media5 & Kegiatan sosialisasi luring/daring yang diselenggarakan oleh Kemendikbud. \\
\hline Media4 & Kanal daring Perguruan Tinggi (laman/website, media sosial). \\
\hline Media3 & Kegiatan sosialisasi luring/daring yang diselenggarakan oleh Perguruan Tinggi. \\
\hline Media2 & Kanal komunikasi komunitas (misal: komunitas alumni, komunitas dosen). \\
\hline Media1 & Media massa. \\
\hline Media0 & Lainnya \\
\hline
\end{tabular}

Tabel 5

Tabulasi silang antara tingkat pemahaman mahasiswa mengenai program MBKM terhadap dengan media informasi yang digunakan mahasiswa untuk mengetahui kebijakan MBKM

\begin{tabular}{cccccc}
\hline \multirow{2}{*}{$\begin{array}{c}\text { Menis } \\
\text { Media }\end{array}$} & $\begin{array}{c}\text { Sangat } \\
\text { Paham }\end{array}$ & Paham & $\begin{array}{c}\text { Cukup } \\
\text { Paham }\end{array}$ & $\begin{array}{c}\text { Kurang } \\
\text { Paham }\end{array}$ & $\begin{array}{c}\text { Kurang } \\
\text { Paham }\end{array}$ \\
\hline Media6 & $0 \%$ & $9,2 \%$ & $10,8 \%$ & $6,2 \%$ & $0 \%$ \\
\hline Media5 & $0 \%$ & $0 \%$ & $1,5 \%$ & $1,5 \%$ & $0 \%$ \\
\hline Media4 & $1,5 \%$ & $9,2 \%$ & $18,5 \%$ & $16,9 \%$ & $1,5 \%$ \\
\hline Media3 & $0 \%$ & $3,1 \%$ & $3,1 \%$ & $3,1 \%$ & $1,5 \%$ \\
\hline Media2 & $0 \%$ & $0 \%$ & $1,5 \%$ & $3,1 \%$ & $1,5 \%$ \\
\hline Media0 & $0 \%$ & $0 \%$ & $3,1 \%$ & $3,1 \%$ & $0 \%$ \\
\hline
\end{tabular}

Pada kuesioner mahasiswa, terdapat pertanyaan nomor lima yang berkaitan dengan analisis pada bagian ini. Pertanyaan nomor lima tersebut berbunyi "Menurut Saudara apa media informasi untuk meningkatkan pemahaman kebijakan Merdeka Belajar-Kampus Merdeka (MBKM) ? Mohon memilih 3 (tiga) yang terbaik". Respon mahasiswa dari pertanyaan ini dapat dilihat pada Gambar 4. Berdasarkan hasil pada Gambar 4, dapat terlihat bahwa empat media dengan persentase responden terbanyak, yaitu Media4, Media5, Media6, dan Media3. Bahwa Media4, Media6, dan Media3 adalah media yang prioritas untuk digunakan sebagai sarana sosialisasi kebijakan MBKM ini sama dengan hasil pada Tabel 5. Hanya pada Gambar 5 ini terdapat tambahan Media5 yang memiliki responden pemilih cukup banyak. Media5 adalah "Kegiatan sosialisasi luring/daring yang diselenggarakan oleh Kemendikbud". Maka berdasarkan hasil analisis yang disajikan pada Tabel 5 dan Gambar 4, direkomendasikan pada pihak Program Studi untuk lebih mengoptimalkan keempat media tersebut dalam melakukan sosialisasi-sosialisasi mengenai kebijakan MBKM ini. Pemanfaatan media sosialisasi luring/daring sebagai media informasi yang efektif juga dilaporkan oleh (Tiasih \& Wenas, 2020; Wulandari et al., 2021). 
739 Analisis Hasil Survei SPADA Dikti 2021 dan Dampaknya Terhadap Rekomendasi Kebijakan Implementasi Kampus Merdeka - Sri Supatmi, Budi Herdiana, Jana Utama, Muhammad Aria Rajasa Pohan, Tri Rahajoeningroem

DOI: https://doi.org/10.31004/edukatif.v4i1.1894

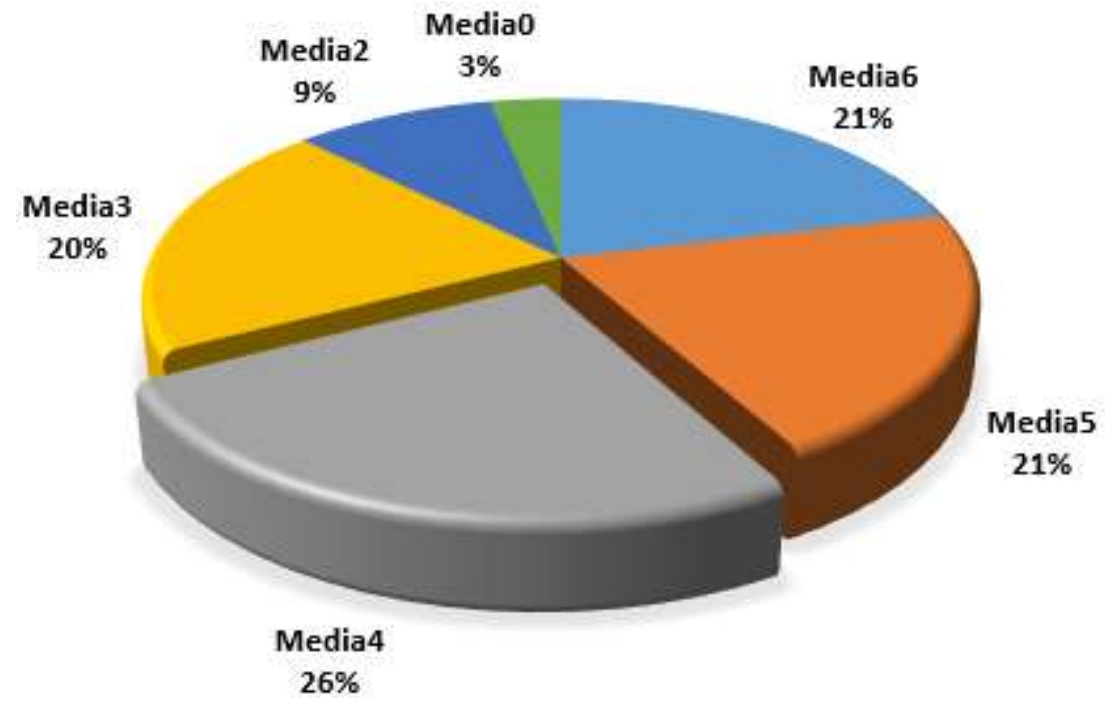

Gambar 4. Hasil opini mahasiswa mengenai media informasi yang terbaik untuk meningkatkan pemahaman tentang kebijakan MBKM

Adapun pada kuesioner dosen juga terdapat pertanyaan nomor lima yang mirip dengan pertanyaan nomor lima pada kuesioner mahasiswa, yaitu berkaitan dengan media informasi yang dianggap paling optimal untuk meningkatkan pemahaman kebijakan Merdeka Belajar-Kampus Merdeka (MBKM). Respon dosen dari pertanyaan ini dapat dilihat pada Gambar 5. Berdasarkan hasil pada Gambar 5, dapat terlihat bahwa dua media dengan persentase responden terbanyak, yaitu Media3 dan Media5. Media3 adalah "Kegiatan sosialisasi luring/daring yang diselenggarakan oleh Perguruan Tinggi", sedangkan Media5 adalah "Kegiatan sosialisasi luring/daring yang diselenggarakan oleh Kemendikbud".

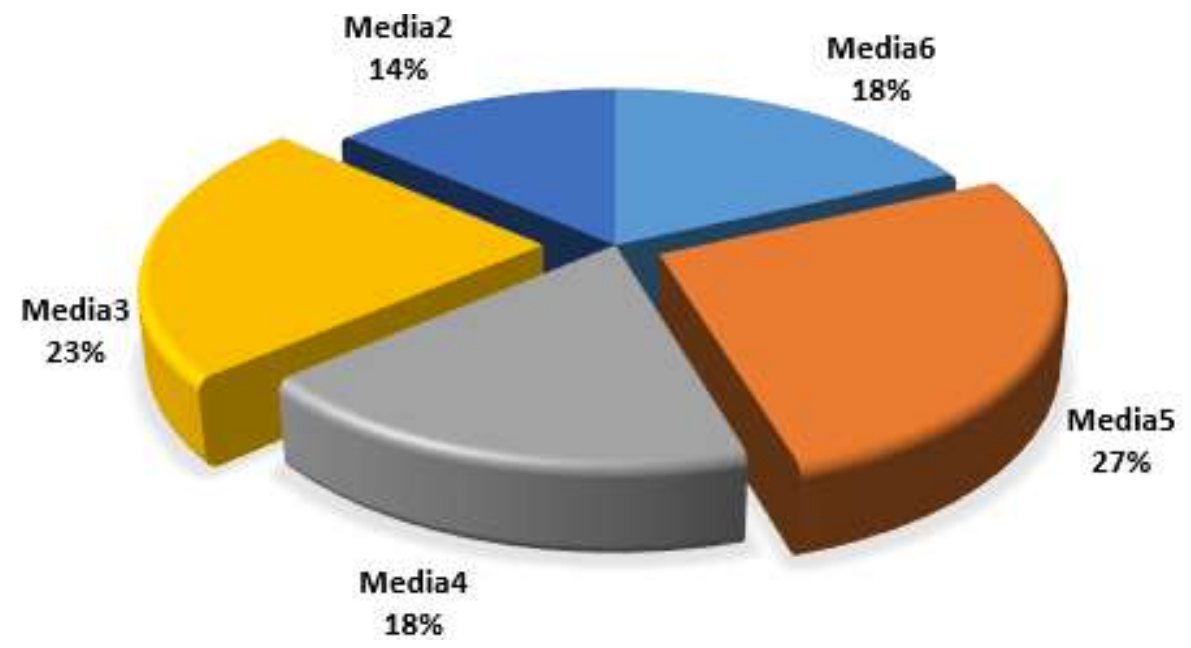

Gambar 5. Hasil opini dosen mengenai media informasi yang terbaik untuk meningkatkan pemahaman tentang kebijakan MBKM

\section{Analisis 3: Opini Responden mengenai Dampak Positif dari Implementasi MBKM}

Pada bagian ini akan dilakukan analisis dari opini responden mengenai apakah program MBKM ini dinilai memiliki dampak yang positif? Pertanyaan-pertanyaan pada kuesioner dianggap dapat merepresentasikan opini responden mengenai dampak dari implementasi program MBKM ini ditunjukkan pada Tabel 6. Nilai numerik dari jawaban pertanyaan setiap mahasiswa untuk nomor 12, 13, 15, 16, 17, dan 19 akan dijumlahkan lalu dirata-ratakan. Nilai rata-rata ini akan dijadikan sebagai nilai tingkat opini responden 
740 Analisis Hasil Survei SPADA Dikti 2021 dan Dampaknya Terhadap Rekomendasi Kebijakan Implementasi Kampus Merdeka - Sri Supatmi, Budi Herdiana, Jana Utama, Muhammad Aria Rajasa Pohan, Tri Rahajoeningroem

DOI: https://doi.org/10.31004/edukatif.v4i1.1894

mahasiswa terhadap dampak dari program MBKM ini. Panduan konversi nilai rata-rata terhadap tingkat dampak dari program MBKM menurut opini mahasiswa ditunjukkan pada Tabel 7. Maka berdasarkan proses pengukuran yang telah dijelaskan pada Tabel 6 dan Tabel 7, dapat diperoleh tingkat pemahaman responden mahasiswa terhadap program MBKM ini seperti yang disajikan pada Gambar 6. Dapat terlihat bahwa sebagian besar responden mahasiswa beropini bahwa implementasi dari program MBKM ini berada pada rentang nilai "Berdampak" (56\% responden).

Tabel 6

Pertanyaan-pertanyaan pada kuesioner mahasiswa yang digunakan untuk mengukur opini responden mengenai dampak dari program MBKM

\begin{tabular}{|c|c|c|c|}
\hline $\begin{array}{c}\text { Nomor } \\
\text { Pertanyaan }\end{array}$ & Isi Pertanyaan & Pilihan Jawaban & $\begin{array}{c}\text { Konversi } \\
\text { Jawaban pada } \\
\text { Nilai Numerik } \\
\end{array}$ \\
\hline \multirow[b]{3}{*}{12} & \multirow{3}{*}{$\begin{array}{l}\text { Menurut saudara, apakah kegiatan } \\
\text { pembelajaran di luar kampus akan } \\
\text { memberikan kompetensi tambahan seperti } \\
\text { keterampilan dalam menyelesaikan } \\
\text { permasalahan nyata }\end{array}$} & $\mathrm{Ya}$ & 5 \\
\hline & & Mungkin & 2,5 \\
\hline & & Tidak Tahu & 0 \\
\hline \multirow{3}{*}{13} & \multirow{3}{*}{$\begin{array}{l}\text { Menurut saudara, belajar di program studi } \\
\text { lain akan memperluas prespektif dan } \\
\text { memberikan kompetensi tambahan yang } \\
\text { dibutuhkan? }\end{array}$} & $\mathrm{Ya}$ & 5 \\
\hline & & Mungkin & 2,5 \\
\hline & & Tidak Tahu & 0 \\
\hline \multirow{4}{*}{15} & \multirow{4}{*}{$\begin{array}{l}\text { Menurut saudara, seberapa manfaat jika } \\
\text { anda mengikuti kegiatan MBKM dalam } \\
\text { pengembangan kompetansi/keterampilan } \\
\text { sebgai bekal bekerja setelah lulus? }\end{array}$} & Sangat Bermanfaat & 5 \\
\hline & & Cukup Bermanfaat & 3,33 \\
\hline & & Kurang Bermanfaat & 1,67 \\
\hline & & Tidak Bermanfaat & 0 \\
\hline \multirow{5}{*}{16} & \multirow{5}{*}{$\begin{array}{l}\text { Menurut saudara, seberapa besar } \\
\text { peningkatan soft-skill yang diperoleh setelah } \\
\text { anda mengikuti kegiatan MBKM dalam } \\
\text { pengembangan kompetensi/keterampilan } \\
\text { sebagai bekal bekerja setelah lulus? }\end{array}$} & $\begin{array}{l}\text { Tidak ada peningkatan } \\
\text { sama sekali }\end{array}$ & 0 \\
\hline & & $\begin{array}{l}\text { Ada peningkatan tapi } \\
\text { kurang baik }\end{array}$ & 1,25 \\
\hline & & $\begin{array}{l}\text { Ada peningkatan cukup } \\
\text { baik }\end{array}$ & 2,5 \\
\hline & & $\begin{array}{l}\text { Ada peningkatan dengan } \\
\text { baik }\end{array}$ & 3,75 \\
\hline & & $\begin{array}{l}\text { Ada peningkatan dengan } \\
\text { sangat baik }\end{array}$ & 5 \\
\hline \multirow{5}{*}{17} & \multirow{5}{*}{$\begin{array}{l}\text { Menurut saudara, seberapa penting MBKM } \\
\text { untuk persiapan menghadapi masa paska } \\
\text { kampus? }\end{array}$} & Sangat Penting & 5 \\
\hline & & Penting & 3,75 \\
\hline & & Cukup Penting & 2,5 \\
\hline & & Kurang Penting & 1,25 \\
\hline & & Tidak Penting & 0 \\
\hline \multirow{3}{*}{19} & \multirow{3}{*}{$\begin{array}{l}\text { Menurut saudara, kegiatan MBKM untuk } \\
\text { perguruan tinggi sesuai dengan kebutuhan } \\
\text { lulusan di masa mendatang? }\end{array}$} & Sangat Sesuai & 5 \\
\hline & & Sesuai & 2,5 \\
\hline & & Tidak Sesuai & 0 \\
\hline
\end{tabular}

Tabel 7

Panduan skala pengukuran tingkat dampak dari program MBKM menurut opini mahasiswa

Nilai rata-rata pertanyaan $12,13,15,16,17, \quad$ Skala pemahaman dan 19 dari responden mahasiswa

\begin{tabular}{cc}
\hline $4-5$ & Sangat Berdampak (SB) \\
\hline $3-4$ & Berdampak (B) \\
\hline
\end{tabular}


741 Analisis Hasil Survei SPADA Dikti 2021 dan Dampaknya Terhadap Rekomendasi Kebijakan Implementasi Kampus Merdeka - Sri Supatmi, Budi Herdiana, Jana Utama, Muhammad Aria Rajasa Pohan, Tri Rahajoeningroem

DOI: https://doi.org/10.31004/edukatif.v4i1.1894

\begin{tabular}{cc}
\hline $2-3$ & Cukup Berdampak (CB) \\
\hline $1-2$ & Kurang Berdampak (KB) \\
\hline $0-1$ & Tidak Berdampak (TB) \\
\hline
\end{tabular}

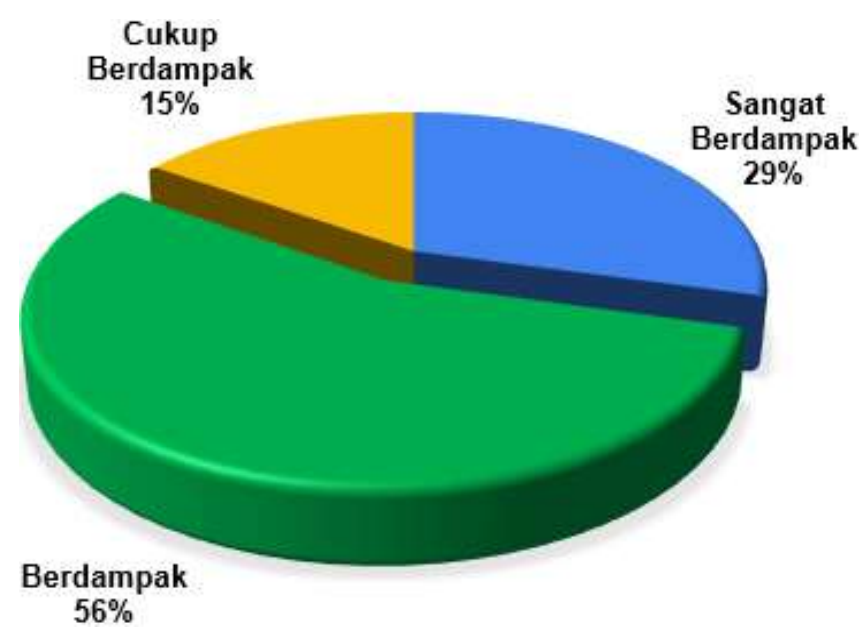

Gambar 6. Hasil analisis tingkat dampak dari program MBKM menurut opini mahasiswa

\section{Analisis 4: Keterkaitan Antara Opini Responden mengenai Dampak MBKM terhadap Bentuk Kegiatan MBKM yang Diminati oleh Mahasiswa}

Berdasarkan hasil analisis 3 di atas, selanjutnya akan dianalisis apakah ada keterkaitan antara opini responden mengenai dampak dari program MBKM ini terhadap jenis kegiatan MBKM yang diminati oleh mahasiswa. Berdasarkan pertanyaan nomor 8 dari kuesioner dengan responden mahasiswa, dapat diketahui jenis kegiatan yang dipilih mahasiswa sebagai bentuk kegiatan pembelajaran di luar program studi. Tabel 7 menunjukkan bentuk-bentuk kegiatan pembelajaran di luar program studi yang dapat dipilih oleh mahasiswa melalui program MBKM ini. Tabulasi silang antara opini mahasiswa mengenai dampak dari kegiatan MBKM dengan kegiatan MBKM yang diminati dapat dilihat pada Tabel 8.

Tabel 8

Bentuk-bentuk kegiatan pembelajaran di luar program studi yang dapat dipilih oleh mahasiswa melalui program MBKM ini

\begin{tabular}{cc}
\hline Kode Media & Deskripsi \\
\hline Kegiatan7 & Pertukaran Pelajar \\
\hline Kegiatan6 & Magang/Praktik Kerja \\
\hline Kegiatan5 & Asistensi Mengajar di Satuan Pendidikan \\
\hline Kegiatan4 & Penelitian/Riset \\
\hline Kegiatan3 & Proyek Kemanusiaan \\
\hline Kegiatan2 & Kegiatan Wirausaha \\
\hline Kegiatan1 & Studi/Proyek Independen \\
\hline Kegiatan0 & Membangun Desa atau Kuliah Kerja Nyata Tematik (KKNT) \\
\hline
\end{tabular}


742 Analisis Hasil Survei SPADA Dikti 2021 dan Dampaknya Terhadap Rekomendasi Kebijakan Implementasi Kampus Merdeka - Sri Supatmi, Budi Herdiana, Jana Utama, Muhammad Aria Rajasa Pohan, Tri Rahajoeningroem

DOI: https://doi.org/10.31004/edukatif.v4i1.1894

Tabel 9

Tabulasi silang antara opini mahasiswa mengenai dampak dari kegiatan MBKM dengan kegiatan MBKM yang diminati

\begin{tabular}{cccccc}
\hline Jenis Media & \multicolumn{5}{c}{ Opini Tingkat Dampak dari Kegiatan MBKM } \\
\cline { 2 - 6 } & $\begin{array}{c}\text { Sangat } \\
\text { Berdampak }\end{array}$ & Berdampak & $\begin{array}{c}\text { Cukup } \\
\text { Berdampak }\end{array}$ & $\begin{array}{c}\text { Kurang } \\
\text { Berdampak }\end{array}$ & $\begin{array}{c}\text { Tidak } \\
\text { Berdampak }\end{array}$ \\
\hline Kegiatan7 & $10,8 \%$ & $6,2 \%$ & $3,1 \%$ & 0 & 0 \\
\hline Kegiatan6 & $12,3 \%$ & $32,3 \%$ & $9,2 \%$ & 0 & 0 \\
\hline Kegiatan5 & 0 & $3,1 \%$ & 0 & 0 & 0 \\
\hline Kegiatan4 & $1,5 \%$ & $4,6 \%$ & 0 & 0 & 0 \\
\hline Kegiatan3 & 0 & 0 & 0 & 0 & 0 \\
\hline Kegiatan2 & $1,5 \%$ & $62 \%$ & $1,5 \%$ & 0 & 0 \\
\hline Kegiatan1 & $1,5 \%$ & 0 & 0 & $1,5 \%$ & 0 \\
\hline Kegiatan0 & $1,5 \%$ & $3,1 \%$ & 0 & 0 & 0 \\
\hline
\end{tabular}

Berdasarkan hasil pada Tabel 8, dapat terlihat bahwa dua bentuk kegiatan pembelajaran di luar program studi yang paling diminati oleh mahasiswa adalah Kegiatan6 dan Kegiatan7. Jika dilihat pada Tabel 5, kedua kegiatan yang paling diminati mahasiswa tersebut adalah "Magang/Praktik Kerja" dan "Pertukaran Pelajar". (Latifah et al., 2021; Lutfia \& Rahadi, 2020) juga melaporkan mengenai pentingnya kegiatan magang/praktik kerja bagi mahasiswa. Sedangkan (Faiz \& Purwati, 2021; Pertiwi \& Pusparini, 2021) telah melaporkan mengenai pentingnya program pertukaran pelajar melalui kurikulum MBKM.

Adapun bentuk kegiatan pembelajaran di luar program studi yang paling tidak diminati oleh mahasiswa adalah Kegiatan3 dan Kegiatan5. Jika dilihat pada Tabel 5, kedua kegiatan yang paling tidak diminati mahasiswa tersebut adalah "Proyek Kemanusiaan" dan "Asistensi Mengajar di Satuan Pendidikan". Maka berdasarkan hasil analisis yang disajikan pada Tabel 8 ini, direkomendasikan kepada pihak program studi untuk lebih mempersiapkan kegiatan di luar program studi bagi mahasiswa dalam bentuk "magang/praktik kerja" dan "pertukaran pelajar". Kepada pihak program studi juga direkomendasikan untuk melakukan sosialisasi mengenai kegiatan "proyek kemanusiaan" dan "asistensi mengajar di satuan pendidikan" kepada mahasiswa agar mahasiswa lebih termotivasi untuk mengikuti kegiatan-kegiatan tersebut.

\section{Analisis 5: Ketertarikan dan Kesiapan Responden Mahasiswa untuk Mengikuti Program MBKM}

Selanjutnya akan dilakukan analisis mengenai ketertarikan dan kesiapan responden mahasiswa untuk mengikuti program MBKM ini. Pertanyaan-pertanyaan pada kuesioner yang dianggap dapat merepresentasikan ketertarikan dan kesiapan responden untuk mengikuti kegiatan MBKM ini ditunjukkan pada Tabel 9. Nilai numerik dari jawaban pertanyaan setiap mahasiswa untuk nomor 10, 20, dan 21 akan dijumlahkan lalu dirata-ratakan. Nilai rata-rata ini akan dijadikan sebagai nilai tingkat ketertarikan dan kesiapan mahasiswa untuk mengikuti program MBKM. Panduan konversi nilai rata-rata terhadap tingkat ketertarikan dan kesiapan mahasiswa untuk mengikuti program MBKM dapat dilihat pada Tabel 10. Maka berdasarkan proses pengukuran yang telah dijelaskan pada Tabel 9 dan Tabel 10, dapat diperoleh tingkat ketertarikan dan kesiapan mahasiswa untuk mengikuti program MBKM ini seperti yang disajikan pada Gambar 7. Dapat terlihat bahwa sebagian besar responden mahasiswa beropini bahwa implementasi dari program MBKM ini berada pada rentang nilai "Cukup Siap" (45\% responden).

Tabel 10

Pertanyaan-pertanyaan pada kuesioner mahasiswa yang digunakan untuk mengukur ketertarikan dan kesiapan responden mahasiswa untuk mengikuti kegiatan MBKM

\begin{tabular}{cccc}
\hline $\begin{array}{c}\text { Nomor } \\
\text { Pertanyaan }\end{array}$ & Isi Pertanyaan & $\begin{array}{c}\text { Pilihan } \\
\text { Jawaban }\end{array}$ & $\begin{array}{c}\text { Konversi Jawaban } \\
\text { pada Nilai } \\
\text { Numerik }\end{array}$ \\
\hline 10 & Apakah saudara sudah menyiapkan diri untuk & Sudah & 5 \\
\hline
\end{tabular}


743 Analisis Hasil Survei SPADA Dikti 2021 dan Dampaknya Terhadap Rekomendasi Kebijakan Implementasi Kampus Merdeka - Sri Supatmi, Budi Herdiana, Jana Utama, Muhammad Aria Rajasa Pohan, Tri Rahajoeningroem

DOI: https://doi.org/10.31004/edukatif.v4i1.1894

\begin{tabular}{llll}
\hline \multirow{2}{*}{} & menjadi bagian dalam kegiatan MBKM ? & Belum & 2,5 \\
\cline { 3 - 4 } & & Tidak & \\
& & Berminat & 0 \\
\hline \multirow{2}{*}{20} & Bagaiman ketertarikan saudara terhadap program & Sangat Tertarik & 5 \\
\cline { 3 - 4 } & MBKM yang diadakan oleh Direktorat Jendral & Biasa saja & 2,5 \\
\cline { 3 - 4 } & Pendidikan Tinggi, Riset dan Teknologi ? & Tidak Tertarik & 0 \\
\hline \multirow{2}{*}{21} & setelah mengetahui secara detail tentang program & Sangat Tertarik & 5 \\
\cline { 3 - 4 } & MBKM, apakah anda akan merekomendasikan & Biasa saja & 2,5 \\
\cline { 3 - 4 } & program ini untuk kolega saudara ? & Tidak Tertarik & 0 \\
\hline
\end{tabular}

Tabel 11

Panduan skala pengukuran tingkat kesiapan dan ketertarikan mahasiswa untuk mengikuti program MBKM

\begin{tabular}{cc}
\hline $\begin{array}{c}\text { Nilai rata-rata pertanyaan 10, 20, dan } 21 \\
\text { dari responden mahasiswa }\end{array}$ & Skala pemahaman \\
\hline $4-5$ & Sangat Siap (SS) \\
\hline $3-4$ & Siap (S) \\
\hline $2-3$ & Ragu-ragu (R) \\
\hline $1-2$ & Kurang Siap (KS) \\
\hline $0-1$ & Tidak Siap (TS) \\
\hline
\end{tabular}

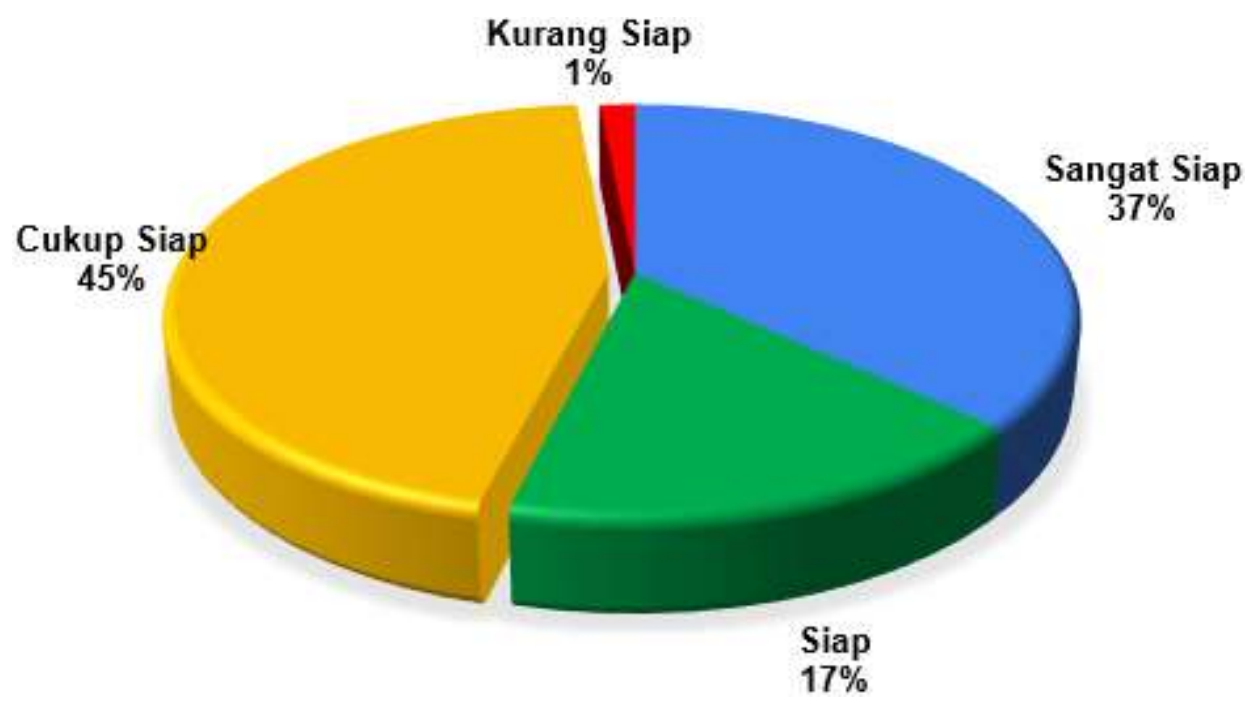

Gambar 7. Hasil analisis tingkat tingkat ketertarikan dan kesiapan mahasiwa untuk mengikuti program MBKM

\section{Analisis 6: Keterkaitan Antara Kesiapan Mahasiswa untuk Mengikuti Program MBKM dengan Kendala yang Dihadapi}

Berdasarkan hasil analisis $5 \mathrm{di}$ atas, selanjutnya akan dianalisis apakah ada keterkaitan antara ketertarikan dan kesiapan mahasiswa untuk mengikuti program MBKM dengan kendali yang dihadapi oleh mahasiswa. Terdapat dua pertanyaan dari kuesioner yang dapat menggambarkan kendala yang dialami oleh mahasiswa untuk mengikuti kegiatan MBKM ini. Kedua pertanyaan tersebut disajikan pada Tabel 11. Mengenai hasil dari jawaban responden mahasiswa mengenai apakah kegiatan MBKM akan berimplikasi pada masa studi, dapat dilihat pada Gambar 8. Dari hasil pada Gambar 8, dapat terlihat bahwa sebagian besar responden $(52 \%)$ tetap menganggap bahwa dengan mengikuti program MBKM ini akan tetap dapat lulus tepat 
744 Analisis Hasil Survei SPADA Dikti 2021 dan Dampaknya Terhadap Rekomendasi Kebijakan Implementasi Kampus Merdeka - Sri Supatmi, Budi Herdiana, Jana Utama, Muhammad Aria Rajasa Pohan, Tri Rahajoeningroem

DOI: https://doi.org/10.31004/edukatif.v4i1.1894

waktu. Hanya sebagian kecil responden (17\%) yang mengkhawatirkan bahwa dengan mengikuti program MBKM ini akan membuat masa studi menjadi lebih lama.

Tabel 12

Pertanyaan-pertanyaan pada kuesioner mahasiswa yang digunakan untuk mengukur ketertarikan dan kesiapan responden mahasiswa untuk mengikuti kegiatan MBKM

\begin{tabular}{|c|c|c|c|}
\hline $\begin{array}{c}\text { Nomor } \\
\text { Pertanyaan }\end{array}$ & Isi Pertanyaan & Pilihan Jawaban & Keterangan \\
\hline \multirow{3}{*}{11} & \multirow{3}{*}{$\begin{array}{l}\text { Menurut saudara, apakah kegiatan } \\
\text { pembelajaran di luar program studi akan } \\
\text { berimplikasi pada masa studi? }\end{array}$} & Masa studi menjadi lama & \\
\hline & & Tetap Tepat Waktu & \\
\hline & & Tidak Tahu & \\
\hline \multirow{5}{*}{18} & \multirow{5}{*}{$\begin{array}{l}\text { Menurut saudara, apa yang menjadi } \\
\text { kekhawatiran ketika melakukan kegiatan } \\
\text { pembelajaran di luar kampus? }\end{array}$} & $\begin{array}{l}\text { Kurang ada dukungan dari } \\
\text { kampus. }\end{array}$ & Kendala1 \\
\hline & & Kurang disetujui orang tua. & Kendala2 \\
\hline & & Kurangnya informasi. & Kendala3 \\
\hline & & Mengeluarkan biaya. & Kendala4 \\
\hline & & Lainnya & Kendala5 \\
\hline
\end{tabular}

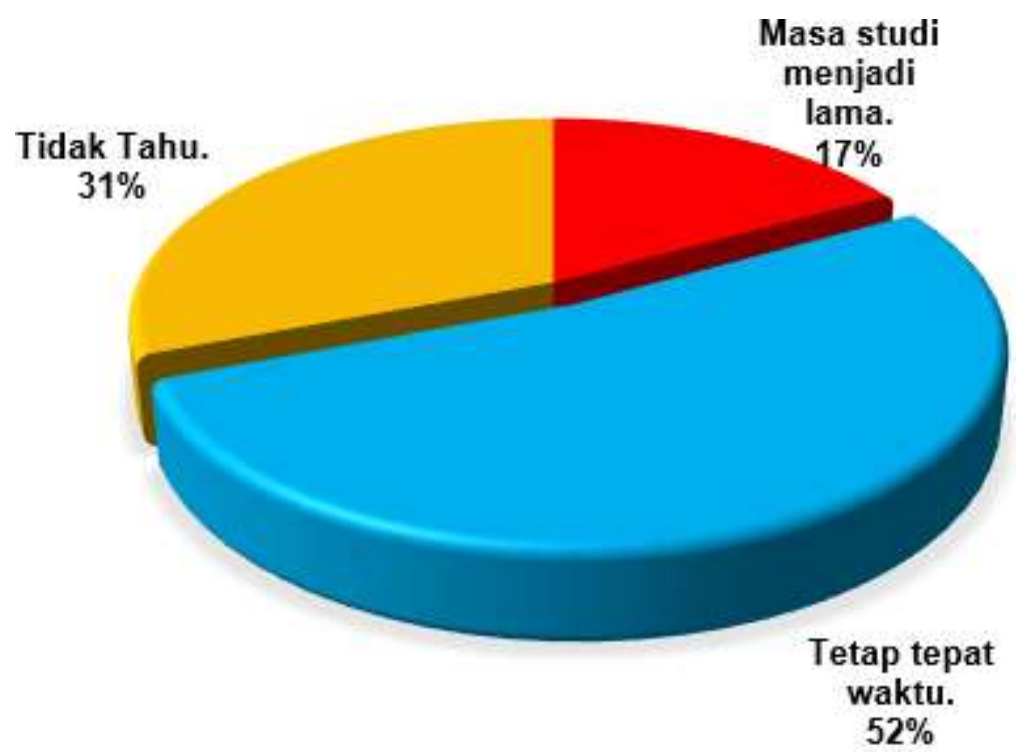

Gambar 8. Hasil analisis mengenai kekhawatiran responden mahasiswa mengenai apakah kegiatan MBKM akan berimplikasi pada masa studi

Tabulasi silang antara kesiapan mahasiswa untuk mengikuti kegiatan MBKM terhadap kekhawatiran mahasiswa untuk mengikuti kegiatan MBKM dapat dilihat pada Tabel 10. Berdasarkan hasil pada Tabel 10, dapat terlihat terdapat tiga kendala yang paling dikhawatirkan mahasiswa sehingga masih ragu-ragu untuk mengikuti kegiatan MBKM ini. Ketiga kendala yang paling dikhawatirkan mahasiswa adalah Kendala3, Kendala4 dan Kendala2. Jika dilihat pada Tabel 9, Ketiga kendala yang paling dikhawatirkan mahasiswa tersebut adalah "Kurangnya informasi", "Mengeluarkan biaya", dan "Kurang disetujui orang tua". Maka berdasarkan hasil analisis yang disajikan pada Tabel 10 ini, direkomendasikan kepada pihak program studi untuk melakukan kegiatan-kegiatan sosialisasi kepada mahasiswa, terutama untuk menyampaikan informasi mengenai deskripsi kegiatan Kampus Merdeka, biaya yang diperlukan, dan memberikan penjelasan kepada pihak orang tua mahasiswa. 
745 Analisis Hasil Survei SPADA Dikti 2021 dan Dampaknya Terhadap Rekomendasi Kebijakan Implementasi Kampus Merdeka - Sri Supatmi, Budi Herdiana, Jana Utama, Muhammad Aria Rajasa Pohan, Tri Rahajoeningroem

DOI: https://doi.org/10.31004/edukatif.v4i1.1894

Tabel 13

Tabulasi silang antara kesiapan mahasiswa untuk mengikuti kegiatan MBKM terhadap kekhawatiran mahasiswa untuk mengikuti kegiatan MBKM

\begin{tabular}{cccccc}
\hline Jenis & \multicolumn{2}{c}{ Kesiapan Mahasiswa untuk Mengikuti Kegiatan MBKM (\%) } \\
\cline { 2 - 6 } Media & Tidak Siap & Kurang Siap & Ragu-ragu & Siap & Sangat Siap \\
\hline Kendala1 & 0 & 0 & 0 & 0 & $1.5 \%$ \\
\hline Kendala2 & 0 & 0 & $12,3 \%$ & $1.5 \%$ & $1.5 \%$ \\
\hline Kendala3 & 0 & $1,5 \%$ & $9,2 \%$ & $6.2 \%$ & $7.7 \%$ \\
\hline Kendala4 & 0 & 0 & $20,0 \%$ & $9.2 \%$ & $26.2 \%$ \\
\hline Kendala5 & 0 & $1,5 \%$ & $1,5 \%$ & 0 & $0.0 \%$ \\
\hline
\end{tabular}

\section{KESIMPULAN}

Adapun kesimpulan yang diambil berdasarkan 3 indikator kinerja penelitian, antara lain: Tingkat pemahaman responden mahasiswa terhadap program MBKM ini, sebagian besar responden mahasiswa beropini bahwa implementasi dari program MBKM ini berada pada rentang nilai "Berdampak" (56\% responden). Kesiapan mahasiswa untuk mengikuti program MBKM, didapatkan bahwa sebagian besar responden mahasiswa beropini bahwa implementasi dari program MBKM ini berada pada rentang nilai "Cukup Siap" yakni sebanyak 45\% responden. Responden mahasiswa mengenai apakah kegiatan MBKM akan berimplikasi pada masa studi, didapatkan sebagian besar responden yakni sebanyak $52 \%$ responden, tetap menganggap bahwa dengan mengikuti program MBKM ini akan tetap dapat lulus tepat waktu. Hanya sebagian kecil responden yakni sebanyak $17 \%$ responden yang mengkhawatirkan bahwa dengan mengikuti program MBKM ini akan membuat masa studi menjadi lebih lama.

\section{UCAPAN TERIMA KASIH}

Program ini didanai oleh Ditjen DIKTIRISTEK untuk program Penelitian Kebijakan MBKM dan PkM berbasis Hasil Penelitian dan Purwarupa PTS 2021

\section{DAFTAR PUSTAKA}

Aunur Rahman, R., Surya, I., \& Kondorura, D. (2020). Efektivitas Pelayanan Informasi Melalui Website Dalam Meningkatkan Kualitas Pelayanan Publik Di Kecamatan Samarinda Ilir Kota Samarinda. 2020(1), 701-711.

Azizah, A. H., Sandfreni, S., \& Ulum, M. B. (2021). Analisis Efektivitas Penggunaan Portal Resmi Merdeka Belajar Kampus Merdeka Menggunakan Model Delone And Mclean. Sebatik, 25(2), 303-310. https://doi.org/10.46984/sebatik.v25i2.1671

Fadillah, A. (2013). Efektivitas Website Sman 5 Samarinda Sebagai Media Komunikasi Dan Informasi Siswa. $1(1), 113-124$.

Faiz, A., \& Purwati, P. (2021). Koherensi Program Pertukaran Pelajar Kurikulum Merdeka Belajar Kampus Merdeka dan General Education. Edukatif: Jurnal Ilmu Pendidikan, 3(3), 649-655. https://doi.org/10.31004/edukatif.v3i3.378

Hambali, Hilmi. ; F. Nurul. ; H. R. ; H. S. M. (2020). Pengaruh Model Project Based Learning (Pjbl) Sebagai Implementasi Kampus Merdeka Terhadap Keterampilan Kolaborasi Mahasiswa Prodi Pendidikan Biologi. In Jurnal Ilmiah Ecosystem (Vol. 20).

Lestiyani, P. (2020). Analisis Persepsi Civitas Akademika Terhadap Konsep Merdeka Belajar Menyongsong Era Industri 5.0. Jurnal Kependidikan: Jurnal Hasil Penelitian Dan Kajian Kepustakaan Di Bidang Pendidikan, Pengajaran Dan Pembelajaran, 6(3), 365. https://doi.org/10.33394/jk.v6i3.2913 
746 Analisis Hasil Survei SPADA Dikti 2021 dan Dampaknya Terhadap Rekomendasi Kebijakan Implementasi Kampus Merdeka - Sri Supatmi, Budi Herdiana, Jana Utama, Muhammad Aria Rajasa Pohan, Tri Rahajoeningroem

DOI: https://doi.org/10.31004/edukatif.v4i1.1894

Lutfia, D. D., \& Rahadi, D. R. (2020). Analisis Internship Bagi Peningkatan Kompetensi Mahasiswa. Jurnal Ilmiah Manajemen Kesatuan, 8(3), 199-204. https://doi.org/10.37641/jimkes.v8i3.340

Latifah, S., Gibran, Z., Saadiah, H., Prasetyawijaya, G., Andy, S. N. C., al Imam, A., Aliyasita, B., Mustika, D., Lasmini, N., \& Ahmad, Z. (2021). Pertukaran Pelajar Unram-UPM: Inovasi Pembelajaran MBKM Dalam Menumbuhkan Ketangguhan Lulusan Sarjana Kehutanan. 2(1).

http://jurnal.lppm.unram.ac.id/index.php/jurnalpepadu/index

Nanggala, Agil.; S. Karim. (2020). Analisis Konsep Kampus Merdeka Dalam Perspektif Pendidikan Kewarganegaraan, Jurnal Global Citizen.

Nurina Aprilia, S., \& Fefta Wijaya, A. (2014). Efektivitas Website Sebagai Media E-Government dalam Meningkatkan Pelayanan Elektronik Pemerintah Daerah (Studi Pada Website Pemerintah Daerah Kabupaten Jombang). 17(2).

Pertiwi, A. K., \& Pusparini, R. (2021). Vocational High School English Teachers' Perspectives On "Merdeka Belajar" Curriculum. Edukatif: Jurnal Ilmu Pendidikan, 3(5), 1982-1992. https://doi.org/10.31004/edukatif.v3i5.672

Prahani, B. K., Deta, U. A., Yasir, M., Astutik, S., Pandiangan, P., Mahtari, S., \& Mubarok, H. (2020). The Concept of "Kampus Merdeka" in Accordance with Freire's Critical Pedagogy. Studies in Philosophy of Science and Education (SiPoSE), 1(1), 21-37. https://doi.org/10.46627/sipose.v1i1.8

Rodiyah, R. (2021). Implementasi Program Merdeka Belajar Kampus Merdeka di Era Digital dalam Menciptakan Karakter Mahasiswa Hukum yang Berkarakter dan Profesional. 7(2), 425-434. https://doi.org/10.15294/snhunnes.v7i2.737

Rosmiati., Putra, I., \& Nasori, A. (2021). Edukatif: Jurnal Ilmu Pendidikan Pengukuran Mutu Pembelajaran di FKIP UNJA dalam Upaya Membangun Generasi Economic Citizen yang Mengelaborasi Program MBKBM Kemendikbud. Edukatif: Jurnal Ilmu Pendidikan, 3. https://doi.org/10.31004/edukatif.v3i6.1356

Rusli Baharuddin, M. (2021). Adaptasi Kurikulum Merdeka Belajar Kampus Merdeka (Fokus: Model MBKM Program Studi). Jurnal Studi Guru Dan Pembelajaran, 4(1). https://doi.org/10.30605/jsgp.4.1.2021.591

Sudaryanto.; Widayati,.; A. Risza. (2020). Konsep Merdeka Belajar-Kampus Merdeka dan Aplikasinya dalam Pendidikan Bahasa (dan Sastra) Indonesia, Jurnal Bahasa, 9(2).

Surentu, Y. Z.;Warouw, D. M. D.; R. Meiske. (2020). Pentingnya Website Sebagai Media Informasi Destinasi Wisata Di Dinas Kebudayaan Dan Pariwisata Kabupaten Minahasa

Tiasih, D. M., \& Wenas, M. B. (2020). Perancangan Media Sosialisasi Sistem Informasi Akademik Satya Wacana Berbasis Video Infografis. International Journal of Natural Science and Engineering, 4(2), 60. https://doi.org/10.23887/ijnse.v4i2.14024

Wulandari, H., Suherman, S., \& Razali, R. (2021). Sosialisasi Sistem Informasi Berbasis Web Dalam Meningkatkan Pengelolaan Data Akademik Sekolah Menengah Kejuruan Madani Marendal I. Reswara: Jurnal Pengabdian Kepada Masyarakat, 2(2), 313-317. https://doi.org/10.46576/rjpkm.v2i2.1150

Yanuarsari, R., Asmadi, I., Suhendraya Muchtar, H., \& Sulastini, R. (2021). Peran Program Merdeka Belajar Kampus Merdeka dalam Meningkatkan Kemandirian Desa. 5(6), 6307-6317. https://doi.org/10.31004/basicedu.v5i6.1828

Yuliana, Yowa.; S. Supeni.; Y. (2020). Analisis Proses Pembelajaran Norma Dan Keadilan Pada PPKN Bagi Siswa Kelas VII SMP Negeri 23 Surakarta., Jurnal Global Citizen. https://doi.org/https://doi.org/10.33061/jgz.v9i2.4132

Yuni, E., Dwi, W., Sudjimat, A., \& Nyoto, A. (2016). Transformasi Pendidikan Abad 21 Sebagai Tuntutan Pengembangan Sumber Daya Manusia di Era Global (Vol. 1). 